\title{
Cyclization of substitued 2-(2-fluorophenylazo)azines to azino[1,2-c]benzo[d][1,2,4]triazinium derivatives
}

\author{
Aleksandra Jankowiak ${ }^{1}$, Emilia Obijalska ${ }^{1, \S}$ and Piotr Kaszynski ${ }^{* 1,2}$
}

\author{
Full Research Paper \\ Address: \\ ${ }^{1}$ Organic Materials Research Group, Department of Chemistry, \\ Vanderbilt University, Nashville, TN 37235 , USA and ${ }^{2}$ Faculty of \\ Chemistry, University of Łódź, Tamka 12, 91403 Łódź, Poland \\ Email: \\ Piotr Kaszynski* - piotr.kaszynski@vanderbilt.edu \\ * Corresponding author \\ $\S$ A visiting student from the laboratory of Professor Grzegorz \\ Mlostoń, Univeristy of Łódź, Poland. \\ Keywords: \\ DFT; heterocycles; mechanism; synthesis
}

\author{
Beilstein J. Org. Chem. 2013, 9, 1873-1880. \\ doi:10.3762/bjoc.9.219 \\ Received: 24 June 2013 \\ Accepted: 19 August 2013 \\ Published: 16 September 2013 \\ Associate Editor: T. J. J. Müller \\ (c) 2013 Jankowiak et al; licensee Beilstein-Institut. \\ License and terms: see end of document.
}

\begin{abstract}
Light-induced cyclization of several substituted 2-(2-fluorophenylazo)azines in the presence of $\mathrm{Ca}^{2+}$ ions to the corresponding triazinium derivatives is investigated experimentally and computationally. The azo derivatives of 4-methylpyridine 4 undergo facile cyclization to the corresponding triazinium $\mathbf{1}$, and the rate of cyclization increases with increasing number of fluorine atoms at the benzene ring. No triazinium ions were obtained from azo derivatives of 4-cyanopyridine, pyrazine and pyrimidine, presumably due to their instability under the reaction conditions. The experimental results and mechanism are discussed with the aid of DFT computational results.
\end{abstract}

\section{Introduction}

Derivatives of benzo[c]quinolizinium [1-4] $(\mathbf{I}, \mathrm{X}=\mathrm{Y}=\mathrm{CH}$, Figure 1) and its di-aza analogue pyrido[2,1-c]benzo$[d][1,2,4]$ triazinium $(\mathbf{I}, \mathrm{X}=\mathrm{Y}=\mathrm{N})$ belong to a class of tricyclic cations featuring general structure $\mathbf{I}$ and are of general interest because of their biological activity. For instance, it was demonstrated that the parent cation 1a intercalates into the minor grove of DNA [5] and to be cytotoxic to cisplatinum-resistant tumor cell lines [6]. Several of its derivatives containing $\mathrm{Cl}, \mathrm{Br}$, $\mathrm{Me}$ and $\mathrm{OMe}$ substituents at the benzene ring were prepared by acid-catalyzed photoinduced cyclization of phenylazopyridines [5]. Recently, we demonstrated an efficient alternative method

for the formation of $\mathbf{1 a}$ and other parent tricyclic azinium cations of general structure $\mathbf{I}(\mathrm{A}=\mathrm{B}=\mathrm{H})$ by light-induced intramolecular cyclization of fluorides II (Figure 1) in the presence of $\mathrm{Ca}^{2+}$ ions [7].
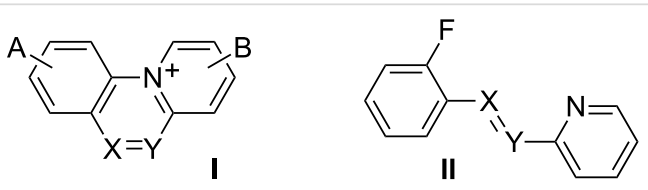

Figure 1: Structures of cations I and precursors II. 
A further progress in the investigation of cation 1a and its applications as a pharmacophore or a component of organic materials requires access to functionalized derivatives, in which substituents control the properties and allow the incorporation into more complex molecular structures. As the first step towards these goals we tested the suitability of our previously described method [7] for the synthesis of several derivatives of 1a and also for two other azines. Initially we selected $\mathrm{CH}_{3}, \mathrm{CN}$ and $\mathrm{F}$ substituents to investigate the reactivity of the azines, and $\mathrm{CH}_{2} \mathrm{OH}$ to provide a potential synthetic handle for the incorporation into more complex structures. Here we present the synthesis of four substituted derivatives of $\mathbf{1 a}$ and investigate the preparation of cations derived from pyrazine 2 and pyrimidine 3 shown in Figure 2. Our experimental results are augmented with DFT computational results.
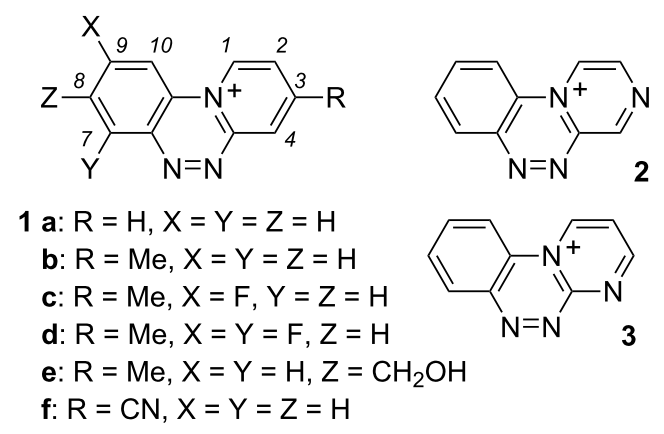

Figure 2: Structures of triazinium cations 1-3.

\section{Results and Discussion \\ Cyclization and cation formation}

Salts 1 were prepared by photocyclization of the corresponding azo derivatives 4 in the presence of $\mathrm{Ca}^{2+}$ ions in aqueous $\mathrm{MeCN}$ (Scheme 1). Diazenes 4 show weak absorption bands in the visible (e.g. $452 \mathrm{~nm}, \log \varepsilon=2.6$ for $\mathbf{4 c}$ ), while salts 1 exhibit only a weak tailing absorption above $400 \mathrm{~nm}$, as shown for $\mathbf{4 c}$ and $\mathbf{1 c}$ in Figure 3. Therefore irradiation was effectively conducted in Pyrex vessels.

$$
\begin{aligned}
& \text { 1a: } R=H, X=Y=Z=H \\
& \text { b: } R=M e, X=Y=Z=H \\
& \text { c: } R=M e, X=F, Y=Z=H \\
& \text { d: } R=M e, X=Y=F, Z=H \\
& \text { e: } R=M e, X=Y=H, Z=C H_{2} O H \\
& \text { f: } R=C N, X=Y=Z=H
\end{aligned}
$$

Scheme 1: Synthesis of triazinium cations 1. Reagents and conditions: i) $h v$ (halogen lamp or sunlight), $\mathrm{Ca}^{2+}, \mathrm{MeCN} / \mathrm{H}_{2} \mathrm{O}(9: 1)$.

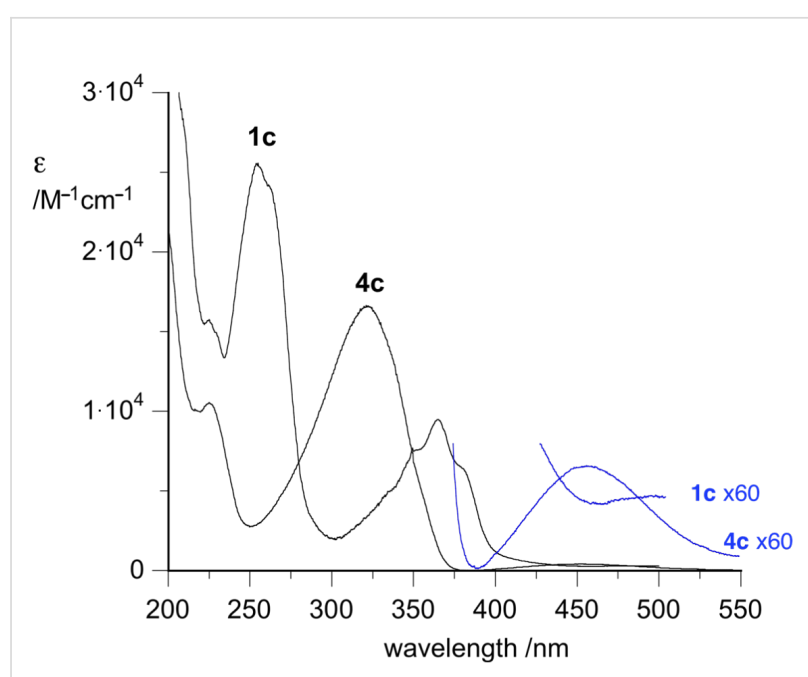

Figure 3: Electronic absorption spectra for 1c and 4c (MeCN). Blue lines represent magnified areas of the spectra.

The cyclization of 2-fluorophenylazopyridines $\mathbf{4 b}$ and $\mathbf{4 e}$ was conducted using a $500 \mathrm{~W}$ halogen lamp in the presence of $\mathrm{Ca}(\mathrm{OTs})_{2}$ [7], and cations $\mathbf{1 b}$ and $\mathbf{1 e}$ were isolated as tosylates in $75 \%$ and $95 \%$ yield, respectively. Under these conditions diazenes $\mathbf{4} \mathbf{c}$ and $\mathbf{4 d}$ underwent cyclization, but the resulting cations 1c and 1d were unstable and partially decomposed during the reaction. Therefore, their cyclization was carried out with sunlight and tosylate 1c was isolated in pure form in $90 \%$ yield. In contrast, cation 1d partially decomposed during the workup, presumably due to the activation by means of the fluorine atoms and their electron-withdrawing effect. A pure sample of $1 \mathbf{d}$ could not be isolated. A comparison of the cyclization rates of the three fluorophenylazo derivatives $\mathbf{4 b}-\mathbf{4 d}$ was conducted in NMR tubes exposed to sunlight. The experiment demonstrated that the rate of cyclization increases with increasing number of fluorine atoms, and after $1 \mathrm{~h}$ conversion of $\mathbf{4 b}$ to $\mathbf{1 b}$ was $30 \%, \mathbf{4 c}$ to cation $1 \mathrm{c} 80 \%$, and $\mathbf{4 d}$ to $\mathbf{1 d}$ was complete. Full conversion of $\mathbf{4 b}$ to $\mathbf{1 b}$ was achieved after $5 \mathrm{~h}$. It should be pointed out that the cyclization and formation of the cations requires both light and $\mathrm{Ca}^{2+}$ ions, and no product formation was observed if one of them is absent. While in most experiments $\mathrm{Ca}(\mathrm{OTs})_{2}$ served as a source of $\mathrm{Ca}^{2+}$, in some other $\mathrm{CaCl}_{2}$ was used, and the $\mathrm{Cl}^{-}$anion was later replaced by $\mathrm{TsO}^{-}$.

Attempts to cyclize the cyano derivative $\mathbf{4 f}$, using a halogen lamp were unsuccessful and after $3 \mathrm{~h}$ only decomposition products were observed by ${ }^{1} \mathrm{H}$ NMR along with some residual starting 4f. No characteristic NMR pattern that could be ascribed to the cation $\mathbf{1 f}$ was detected. Similarly unsuccessful were the attempts to cyclize azopyrazine 5 (halogen lamp/ice bath or sunlight, Figure 4) and azopyrimidine 6 (halogen lamp/ reflux); instead complex mixtures of products were obtained. 
<smiles>Fc1ccccc1N=Nc1cnccn1</smiles><smiles>Fc1ccccc1N=Nc1ncccn1</smiles>

Figure 4: Strcutures of trans azo derivatives 5-E and 6-E.

\section{Synthesis of azo precursors}

Azo compounds $4 \mathbf{b}-\mathbf{4 e}$ were prepared in $38 \%-90 \%$ yield using method A (Scheme 2) in which 2-nitroso-4-picoline (7) [8] was condensed with 2-fluoroaniline $(\mathbf{8 a})$ or its derivatives $\mathbf{8 c}-\mathbf{8 e}$. The 2-fluoro-5-hydroxymethylaniline (8e) was obtained according to a literature procedure [9]. 4-Cyano derivative $\mathbf{4 f}$ was prepared in $50 \%$ yield by method B $[7,10]$ involving condensation of 2-amino-4-cyanopyridine with 1-fluoro-2nitrosobenzene (9) [7]. Azoazines 5 and 6 were obtained in a similar way by condensation of $\mathbf{9}$ with 2 -aminopyrazine and 2 -aminopyrimidine, respectively, and their preparation was described before [11].

Interestingly, the trifluoro derivative $4 \mathbf{d}$ had exceptionally limited thermal stability: After heating at $60{ }^{\circ} \mathrm{C}$ in $\mathrm{CDCl}_{3}$ it was converted to another species also containing the picoline fragment, according to the ${ }^{1} \mathrm{H}$ NMR analysis. The new compound did not undergo photocyclization and was not analyzed further.

\section{Mechanistic and computational analyses}

The proposed mechanism for the formation of the triazinium cations from fluorophenylazoazines involves a photo-induced trans-to-cis isomerization of the azo group followed by $\mathrm{Ca}^{2+}$. assisted cyclization (Scheme 3) [7], which, in principle, can proceed either thermally or photochemically. Thus, the success of the reaction depends on i) the efficient access to the $Z$-isomer, and ii) the relative rates of cyclization vs back isomerization to the $E$-isomer. The supply of the requisite $Z$-isomers of the azoazines is best accomplished by photoisomerization of the $E$-isomers, since the $Z$-isomers cannot be populated thermally due to the high $E \rightarrow Z$ thermal isomerization barrier $\left(\Delta G^{\star} 298>35 \mathrm{kcal} / \mathrm{mol}\right)$ [7]. The $Z$-forms however, thermally and also photochemically isomerize back to the more stable $E$-isomers, and the rates are substituent depended [12]. Thus, with the broadband irradiation a photostationary state establishes providing a constant ratio of $Z$ - to $E$-isomers.

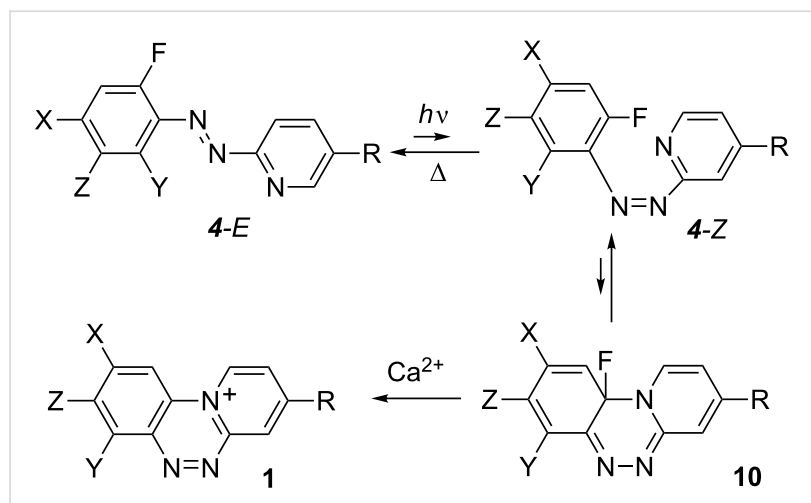

Scheme 3: Formation of cations 1 from diazenes 4

Previous analyses suggested [7] that the cyclization of 4- $Z$ involves $6 \pi$ electrons leading to non-aromatic product $\mathbf{1 0}$, which upon $\mathrm{Ca}^{2+}$-assisted departure of the fluoride undergoes aromatization and formation of cation $\mathbf{1}$. In this work, the theoretical analysis is concentrated on the effect of substituents and on the type of azine on the formation of the cations. Therefore the cyclization of $c i s$-azoazines $4-Z-6-Z$ was investigated at B3LYP/6-311+G(2d,p)//B3LYP/6-311G(2d,p) level of theory in $\mathrm{MeCN}$ as dielectric medium without participation of metal ions. The computational studies were expanded by inclusion of $4 \mathrm{~g}-Z-\mathbf{4} \mathbf{i}-Z$ for a better understanding of the structure-reactivity

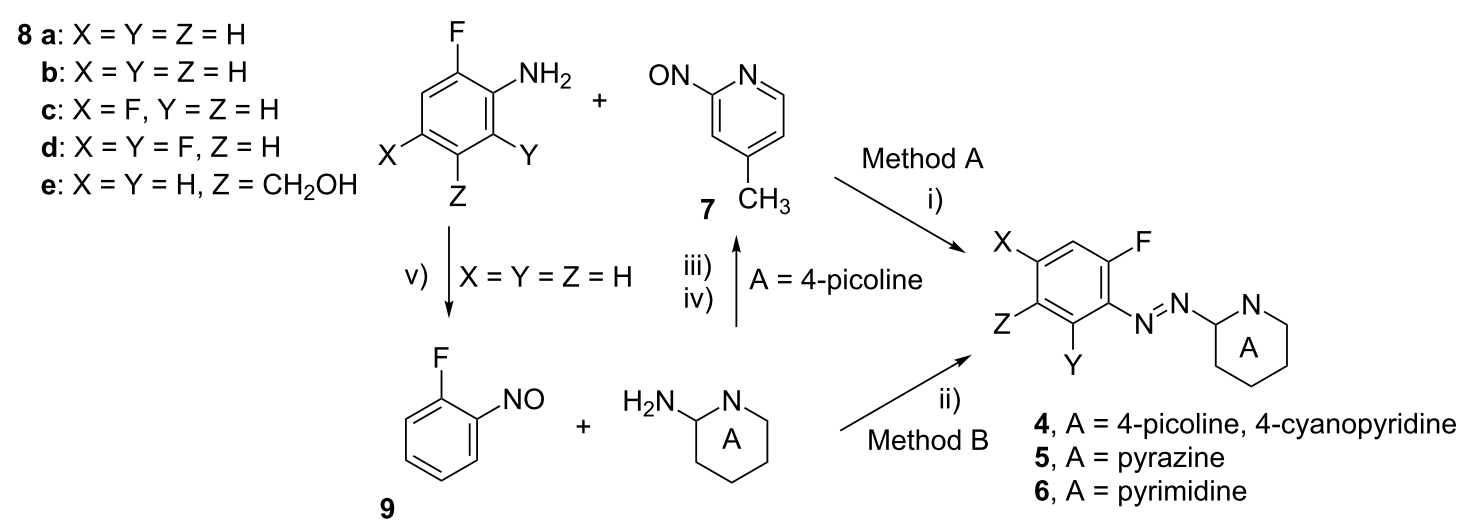

Scheme 2: Synthesis of azo precursors. Reagents and conditions: i) $\mathrm{AcOH}$ cat, $\mathrm{CH}_{2} \mathrm{Cl}_{2}$, rt, $25 \mathrm{~h}$; ii) toluene, $50 \% \mathrm{NaOH}, 50{ }^{\circ} \mathrm{C}, 25 \mathrm{~min}$; iii) $\mathrm{NCS}$, $\mathrm{Me}_{2} \mathrm{~S}, \mathrm{CH}_{2} \mathrm{Cl}_{2},-20^{\circ} \mathrm{C}$; iv) mCPBA, $\mathrm{CH}_{2} \mathrm{Cl}_{2}, 0^{\circ} \mathrm{C}$; v) Oxone ${ }^{\circledR}, \mathrm{CH}_{2} \mathrm{Cl}_{2} / \mathrm{H}_{2} \mathrm{O}$ rt, $25 \mathrm{~h}$. 
relationship. The resulting free energy differences between the $Z$-isomers, relevant to the cyclization process, and the cyclic products, and free energy of activation for a series of diazenes are listed in Table 1 and Table 2.

Table 1: Calculated free energy activation and change $(\mathrm{kcal} / \mathrm{mol})$ for the cyclization of cis-azopyridine $4-Z$ to the nonaromatic product 10 in $\mathrm{MeCN}(\text { Scheme } 3)^{a}$

\begin{tabular}{ccccccc} 
& $\mathrm{R}$ & $\mathrm{X}$ & $\mathrm{Y}$ & $\mathrm{Z}$ & $\Delta G^{\ddagger}{ }_{298}{ }^{\mathrm{b}}$ & $\Delta G_{298}{ }^{\mathrm{c}}$ \\
\hline a & $\mathrm{H}$ & $\mathrm{H}$ & $\mathrm{H}$ & $\mathrm{H}$ & 22.4 & 5.7 \\
$\mathbf{b}$ & $\mathrm{Me}$ & $\mathrm{H}$ & $\mathrm{H}$ & $\mathrm{H}$ & 23.1 & 5.7 \\
c & $\mathrm{Me}$ & $\mathrm{F}$ & $\mathrm{H}$ & $\mathrm{H}$ & 18.5 & 2.4 \\
d & $\mathrm{Me}$ & $\mathrm{F}$ & $\mathrm{F}$ & $\mathrm{H}$ & 18.9 & 4.6 \\
$\mathbf{f}$ & $\mathrm{CN}$ & $\mathrm{H}$ & $\mathrm{H}$ & $\mathrm{H}$ & 23.3 & 5.2 \\
g & $\mathrm{OMe}$ & $\mathrm{H}$ & $\mathrm{H}$ & $\mathrm{H}$ & 23.5 & 4.5 \\
h & $\mathrm{Me}$ & $\mathrm{H}$ & $\mathrm{H}$ & $\mathrm{OMe}$ & 23.2 & 3.9 \\
i & $\mathrm{Me}$ & $\mathrm{H}$ & $\mathrm{H}$ & $\mathrm{CN}$ & 19.0 & 4.8 \\
\hline
\end{tabular}

${ }^{a}$ Calculations at B3LYP/6-311+G(2d,p)//B3LYP/6-311G(2d,p) level with $\mathrm{MeCN}$ as dielectric medium. ${ }^{\mathrm{b}}$ Energy of the transition state 10-TS ${ }^{\mathrm{C} E n e r g y ~ d i f f e r e n c e ~ b e t w e e n ~ p r o d u c t ~} 10$ and azopyridine $4-Z$.

Table 2: Calculated free energy activation and change (kcal/mol) for cyclization of cis-azoazines to the nonaromatic product in $\mathrm{MeCN}$. $^{a}$

\begin{tabular}{ccc} 
reaction & $\Delta G^{\ddagger}{ }_{298^{b}}$ & $\Delta G_{298^{c}}$ \\
\hline $4 a-Z \rightarrow 10 a$ & 22.4 & 5.7 \\
$5-Z \rightarrow 11$ & 18.7 & 2.7 \\
$6-Z \rightarrow 12$ & 25.0 & 7.5 \\
\hline
\end{tabular}

${ }^{a}$ Calculations at B3LYP/6-311+G(2d,p)//B3LYP/6-311G(2d,p) level in $\mathrm{MeCN}$ as dielectric medium. ${ }^{\mathrm{b}}$ Energy of the transition state. ${ }^{\mathrm{C} E n e r g y}$ difference between the cyclic product and azoazine.

The results in Table 1 and Table 2 show that the free energy of activation, $\Delta G^{\ddagger} 298$, required for the cyclization of all considered azoazines is in a range of $18-25 \mathrm{kcal} / \mathrm{mol}$, and the process is endergonic by about $5 \mathrm{kcal} / \mathrm{mol}$. Thus, for all investigated compounds the cyclization is thermally accessible and also thermally reversible at ambient temperature. These computational results are consistent with experimental observations, that all azoazines reacted, however only 5 cations $(\mathbf{1 a}-\mathbf{1 e})$ were isolated. The remaining cations, $\mathbf{1 f}, \mathbf{2}$ and $\mathbf{3}$, could have been formed, but were presumably unstable under the reaction conditions, as already observed for $\mathbf{1 d}$. Also consistent with the computational results is the observation that the formation of $\mathbf{1}$ requires a fluoride scavenger, apparently for the aromatization of the cyclic product.

The analysis of species involved in the cyclization demonstrates that the $\mathrm{C} \cdots \mathrm{N}$ and $\mathrm{C}-\mathrm{F}$ distances change similarly for all azoazines in the process regardless of the substituent. Thus, the $\mathrm{C} \cdots \mathrm{N}$ distance decreases by $1.232 \AA$ from $3.150 \pm 0.03 \AA$ in the cis-azoazine to $1.918 \pm 0.009 \AA$ in the transition state (TS) and then to $1.457 \pm 0.004 \AA$ in the cycloadduct, as shown for the cyclization of $4 \mathbf{c}$ to $10 \mathrm{c}$ in Figure 5 . At the same time the $\mathrm{C}-\mathrm{F}$ distance increases only by about $2 \%$ from $1.350 \pm 0.002 \AA$ in the cis-azoazine to $1.374 \pm 0.003 \AA$ in the TS. A more significant increase in the $\mathrm{C}-\mathrm{F}$ distance, by $7 \%$, is observed in the cyclic product $(1.445 \pm 0.005 \AA)$.

A detailed analysis of the DFT results for the azopyridine series demonstrates that the rate of cyclization only correlates with the character of the substituent at the benzene ring and does not depend on the pyridine ring. For a simple nucleophilic aromatic ipso-substitution reaction (NAS) electron-donating groups in the $\mathrm{C}(4)$ position of the pyridine ring in $\mathbf{4}$ should increase the reaction rate. Computational results demonstrate the contrary and as the electron donation of the substituent $\mathrm{R}$ increases in the order $\mathrm{H}(\mathbf{4 a})<\mathrm{CH}_{3}(\mathbf{4 b})<\mathrm{OCH}_{3}(\mathbf{4 g})$ so does the activation energy (Table 1). In contrast, increasing electron withdrawing ability of the substituent $\mathrm{Z}$ in the para-position to the

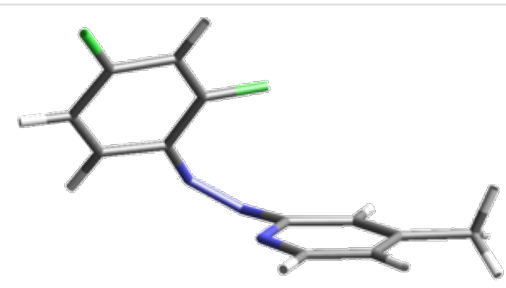

$4 c-Z$

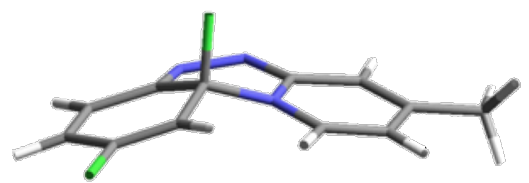

10c

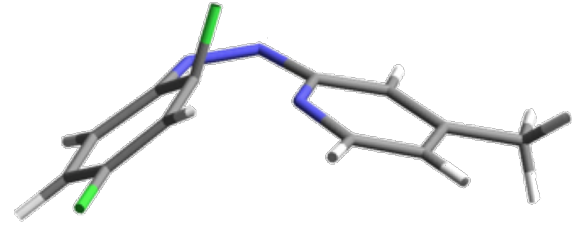

10c-TS

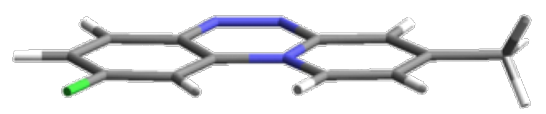

$1 c$

Figure 5: B3LYP/6-311G(2d,p)-optimized geometries for structures involved in cyclization of 4c to 1c. 
leaving fluorine atom increases the reaction rate as observed in a series $4 \mathbf{h}\left(\mathrm{Z}=\mathrm{OCH}_{3}, \Delta G^{\ddagger} 298=23.2 \mathrm{kcal} / \mathrm{mol}\right)$, 4a $\left(\mathrm{Z}=\mathrm{H}, \Delta G^{\dagger} 298=22.4 \mathrm{kcal} / \mathrm{mol}\right)$, and $4 \mathbf{i}(\mathrm{Z}=\mathrm{CN}$, $\left.\Delta G^{\ddagger} 298=19.0 \mathrm{kcal} / \mathrm{mol}\right)$ in Table 1 .

For further probing of the cyclization mechanism, the mildly activating $[13,14] \mathrm{N}=\mathrm{N}$-bridging group in $\mathbf{4} \mathbf{c}-Z$ was replaced by the non-activating $\mathrm{CH}=\mathrm{CH}$ group in $\mathbf{1 3 -} Z$ (Figure 6). A computational analysis demonstrated that this structural modification resulted in a modest increase of activation energy $\Delta G^{\ddagger} 298$ for the cyclization by $3.1 \mathrm{kcal} / \mathrm{mol}$. However, replacement of the bridging $\pi$-bond with the aliphatic $\mathrm{CH}_{2} \mathrm{CH}_{2}$ group in compound 14 prevents the cyclization process, and the analogous cyclic product could not be located on the potential energy surface. These results indicate that the cyclization process involves $6 \pi$ electrons, which allows the formation of the nonzwitterionic product such as $\mathbf{1 0}$. Comparison of cyclization of $\mathbf{4 c}-Z$ and $\mathbf{1 3 -} Z$ further demonstrates that the activation energy is lower for the azene than for the analogues stilbene, which presumably is related to the electronegativity of the bridging group.

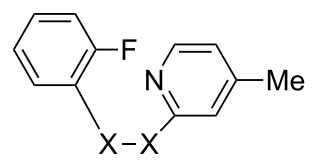

4c- $Z, X-X=N=\mathrm{N}$

13- $\mathrm{Z}, \mathrm{X}-\mathrm{X}=\mathrm{CH}=\mathrm{CH}$

14, $\mathrm{X}-\mathrm{X}=\mathrm{CH}_{2} \mathrm{CH}_{2}$

Figure 6: Structures of three close analogues.

The analysis of the data of three fluoro derivatives $\mathbf{4 b} \mathbf{b} \mathbf{4 d}$ in Table 1 demonstrates that the addition of one or two fluorine atoms at the benzene ring in $\mathbf{4 b}$ significantly lowers the activation barrier for the cyclization, by about $4.5 \mathrm{kcal} / \mathrm{mol}$, for $\mathbf{4 c}-\boldsymbol{Z}$ and $\mathbf{4 d}-\boldsymbol{Z}$, which is consistent with the accellerated formation of cations $1 \mathbf{c}$ and $\mathbf{1 d}$ observed experimentally. Interestingly, a bigger effect is predicted for the 2,4-difluorophenyl derivative $\mathbf{4 c}$ than for the 2,4,6-trifluorophenyl analogue $\mathbf{4 d}$

Among the three parent azoazines the least unfavorable cyclization is calculated for the pyrazine derivative $5-Z$ $\left(\Delta G_{298}=2.7 \mathrm{kcal} / \mathrm{mol}\right)$, which also has the lowest TS energy $\left(\Delta G^{\ddagger} 298=18.7 \mathrm{kcal} / \mathrm{mol}\right.$, Table 2$)$. On the other hand, the cyclization of pyrimidine $6-Z$ is most endergonic and has the highest TS energy among all azoazines considered in this work. These significant differences between the three parent azoazines can be explained with lower aromaticity of the pyrazine ring [15], and with the electropositive character of the $\mathrm{N}(1)$ position of the pyrimidine ring, when compared to the pyridine analogue. These two factors may also contribute to the higher reactivity of cations $\mathbf{2}$ and $\mathbf{3}$ and hence their apparent instability under the reaction conditions.

\section{Conclusion}

A DFT computational analysis indicates that the cyclization of cis-fluorophenylazoazines can occur thermally at room temperature for all considered compounds. The reaction is endergonic with $2.4-7.5 \mathrm{kcal} / \mathrm{mol}$, and the formation of the triazinium cations is accomplished by aromatization of the cyclic product by $\mathrm{Ca}^{2+}$ ion-assisted removal of the fluoride. These results are supported by experimental data, which demonstrate a facile conversion of all azoazines under the reaction conditions, although only 5 out of 8 triazinium salts were isolated. The remaining three, all of them containing a $\mathrm{CN}$ substituent and derived from pyrazine and pyrimidine, are presumably too reactive under the reaction conditions to be isolated in pure form.

A brief computational investigation of the mechanism demonstrates the importance of the unsaturated bridge in the cyclization step and points towards a $6 \pi$-electrocyclization rather than to a simple nucleophilic aromatic displacement mechanism.

Among the triazinium salts prepared in this work is the hydroxymethyl derivative 1e, which, in principle, can be incorporated into more complex molecular structures.

\section{Computational Details}

The quantum-mechanical calculations were carried out at B3LYP/6-311G(2d,p) level of theory using the Gaussian 09 suite of programs [16]. The geometry optimizations were undertaken using tight convergence limits and with no symmetry constraints. Vibrational frequencies were used to characterize the nature of the stationary points. Zero-point energy (ZPE) corrections were scaled by 0.9806 [17]. Transition state structures for cyclization reactions were located using the STQN method [18] requested with the QST2 keyword and default convergence criteria. Final energies for each optimized structure were calculated with the B3LYP/6-311+G(2d,p)//B3LYP/ 6-311G(2d,p) method in $\mathrm{MeCN}$ as dielectric medium using the IPCM model [19] requested with the SCRF=IPCM keyword $($ epsilon $=36.64)$.

\section{Experimental \\ General remarks}

Melting points are uncorrected. NMR spectra were recorded at $300 \mathrm{MHz}\left({ }^{1} \mathrm{H}\right)$ and $100 \mathrm{MHz}\left({ }^{13} \mathrm{C}\right)$ in $\mathrm{CD}_{3} \mathrm{CN}$, DMSO- $d_{6}$ or $\mathrm{CDCl}_{3}$ and chemical shifts are refered to the solvent peaks (1.96, 2.54 and $7.26 \mathrm{ppm}$, respectively). 


\section{Photocyclization and preparation of salts 1 . General Porcedure}

Method A [7]: Azo compound $4(1.0 \mathrm{mmol})$ and calcium $p$-toluenesulfonate $(190 \mathrm{mg} 0.5 \mathrm{mmol})$ or calcium chloride (56 mg, $0.5 \mathrm{mmol}$ ) were dissolved in a mixture of $\mathrm{MeCN} / \mathrm{H}_{2} \mathrm{O}$ $(9: 1,30 \mathrm{~mL})$. The resulted solution was irradiated with a $500 \mathrm{~W}$ halogen lamp and gently refluxed until TLC control showed full conversion of the substrate (about $1.5 \mathrm{~h}$ ). The solvents were evaporated. The residue was dried in a desiccator over $\mathrm{P}_{2} \mathrm{O}_{5}$ (12 h). The solid was washed with $\mathrm{CH}_{2} \mathrm{Cl}_{2}$, the residue was dissolved in hot $\mathrm{MeCN}$ and filtered. The solvent was evaporated and the crude product was recrystallized from aqueous $\mathrm{MeCN}$

Method B: The reaction mixture prepared as in method A was exposed to intense sunlight, while stirring until TLC control showed full conversion of the substrate (about $1.5 \mathrm{~h}$ ). The workup of the reaction mixture was as described in method A.

3-Methylpyrido[2,1-c][1,2,4]benzotriazin-11-ium p-toluenesulfonate (1b): Method A, yield 95\%: ${ }^{1} \mathrm{H}$ NMR (300 MHz, $\left.\mathrm{CD}_{3} \mathrm{CN}\right) \delta 2.33(\mathrm{~s}, 3 \mathrm{H}), 2.98(\mathrm{~s}, 3 \mathrm{H}), 7.16(\mathrm{~d}, J=7.8 \mathrm{~Hz}, 2 \mathrm{H})$, $7.60(\mathrm{~d}, J=8.0 \mathrm{~Hz}, 2 \mathrm{H}), 8.35(\mathrm{t}, J=7.8 \mathrm{~Hz}, 1 \mathrm{H}), 8.43(\mathrm{~d}$, $J=7.5 \mathrm{~Hz}, 1 \mathrm{H}), 8.49$ (t, $J=8.1 \mathrm{~Hz}, 1 \mathrm{H}), 8.83(\mathrm{~d}, J=8.8 \mathrm{~Hz}$ $1 \mathrm{H}), 9.03(\mathrm{~d}, J=8.0 \mathrm{~Hz}, 1 \mathrm{H}), 9.12(\mathrm{~s}, 1 \mathrm{H}), 9.87(\mathrm{~d}, J=7.0 \mathrm{~Hz}$ $1 \mathrm{H}$ ); HRMS $\mathrm{m} / z$ calcd for $\mathrm{C}_{12} \mathrm{H}_{10} \mathrm{~N}_{3}, 196.0869$; found 196.0892 .

9-Fluoro-3-methylpyrido[2,1-c] $[1,2,4]$ benzotriazin-11-ium p-toluenesulfonate (1c): Method $\mathrm{B}$, yield 90\%: $\mathrm{mp}>190{ }^{\circ} \mathrm{C}$ dec.; ${ }^{1} \mathrm{H}$ NMR (300 MHz, CD $\left.{ }_{3} \mathrm{CN}\right) \delta 2.35$ (s, 3H), $2.96(\mathrm{~s}, 3 \mathrm{H})$ $7.19(\mathrm{~d}, J=7.5 \mathrm{~Hz}, 2 \mathrm{H}), 7.60(\mathrm{~d}, J=7.1 \mathrm{~Hz}, 2 \mathrm{H}), 8.11(\mathrm{t}$, $J=7.8 \mathrm{~Hz}, 1 \mathrm{H}), 8.44(\mathrm{~d}, J=6.7 \mathrm{~Hz}, 1 \mathrm{H}), 8.64\left(\mathrm{dd}, J_{1}=9.2 \mathrm{~Hz}\right.$ $\left.J_{2}=2.2 \mathrm{~Hz}, 1 \mathrm{H}\right), 9.00-9.60(\mathrm{~m}, 1 \mathrm{H}), 9.11(\mathrm{~s}, 1 \mathrm{H}), 9.73(\mathrm{~d}$, $J=6.8 \mathrm{~Hz}, 1 \mathrm{H}) ;{ }^{13} \mathrm{C}$ NMR $\left(100 \mathrm{MHz}, \mathrm{DMSO}-d_{6}\right) \delta 20.8,21.8$, $104.1(\mathrm{~d}, J=30 \mathrm{~Hz}), 121.8$ (d, $J=25 \mathrm{~Hz}), 125.5,128.0,129.7$, 130.2, 132.3, 135.7 (d, $J=11 \mathrm{~Hz}), 137.5,138.9,141.9,145.8$, 160.6; UV-vis (MeCN) $\lambda_{\max }(\log \varepsilon) 225$ (4.20), 254 (4.41), 262 sh (4.38), 365 (3.98), 379 sh (3.81); anal. calcd for $\mathrm{C}_{19} \mathrm{H}_{16} \mathrm{FN}_{3} \mathrm{O}_{3} \mathrm{~S}: \mathrm{C}, 59.21 ; \mathrm{H}, 4.18 ; \mathrm{N}, 10.90$; found: $\mathrm{C}, 58.92$; $\mathrm{H}, 4.09 ; \mathrm{N}, 10.95$.

7,9-Difluoro-3-methylpyrido[2,1-c] $[1,2,4]$ benzotriazin-11ium chloride (1d): Method B, yield 40-80\% (based on NMR): ${ }^{1} \mathrm{H}$ NMR $\left(300 \mathrm{MHz}, \mathrm{CD}_{3} \mathrm{CN}\right) \delta 2.98(\mathrm{~s}, 3 \mathrm{H}), 7.99(\mathrm{t}$, $J=8.1 \mathrm{~Hz}, 1 \mathrm{H}), 8.49(\mathrm{~d}, J=5.5 \mathrm{~Hz}, 1 \mathrm{H}), 8.56(\mathrm{~d}, J=8.9 \mathrm{~Hz}$, $1 \mathrm{H}), 9.16(\mathrm{~s}, 1 \mathrm{H}), 9.77(\mathrm{~d}, J=6.8 \mathrm{~Hz}, 1 \mathrm{H})$.

8-Hydroxymethyl-3-methylpyrido $[2,1-c][1,2,4]$ benzotriazin11-ium p-toluenesulfonate (1e): Method A, yield 75\%: $\mathrm{mp}>150{ }^{\circ} \mathrm{C}$ dec.; ${ }^{1} \mathrm{H}$ NMR $\left(300 \mathrm{MHz}, \mathrm{DMSO}-d_{6}\right) \delta 2.32(\mathrm{~s}$,
$3 \mathrm{H}), 2.98(\mathrm{~s}, 3 \mathrm{H}), 4.97(\mathrm{~d}, J=5.0 \mathrm{~Hz}, 2 \mathrm{H}), 5.92(\mathrm{t}, J=5.5 \mathrm{~Hz}$, $1 \mathrm{H}), 7.14(\mathrm{~d}, J=7.8 \mathrm{~Hz}, 2 \mathrm{H}), 7.50(\mathrm{~d}, J=8.0 \mathrm{~Hz}, 2 \mathrm{H}), 8.49$ (d, $J=8.5 \mathrm{~Hz}, 1 \mathrm{H}), 8.64(\mathrm{~d}, J=5.5 \mathrm{~Hz}, 1 \mathrm{H}), 8.95(\mathrm{~s}, 1 \mathrm{H}), 9.17(\mathrm{~d}$, $J=8.9 \mathrm{~Hz}, 1 \mathrm{H}), 9.35(\mathrm{~s}, 1 \mathrm{H}), 10.36(\mathrm{~d}, J=6.8 \mathrm{~Hz}, 1 \mathrm{H})$; ${ }^{13} \mathrm{C}$ NMR $\left(100 \mathrm{MHz}, \mathrm{DMSO}-d_{6}\right) \delta 20.8,21.6,61.6,116.4$, $121.8,125.5,128.0,128.1,129.6,130.2,131.9,136.6,137.6$, $141.2,142.0,145.7,148.2,159.2$; anal. calcd for $\mathrm{C}_{20} \mathrm{H}_{19} \mathrm{~N}_{3} \mathrm{O}_{4} \mathrm{~S}: \mathrm{C}, 60.44 ; \mathrm{H}, 4.82 ; \mathrm{N}, 10.57$; found: $\mathrm{C}, 60.15 ; \mathrm{H}$, $4.78 ; \mathrm{N}, 10.47$.

\section{Azo compounds 4. A general procedure}

Method A. To the solution of amine $(1.0 \mathrm{mmol})$ in dry $\mathrm{CH}_{2} \mathrm{Cl}_{2}$ (2 mL), 2-nitroso-4-picoline (7, $1.0 \mathrm{mmol})$ was added followed by a catalytic amount ( 1 drop) of acetic acid. The reaction mixture was stirred at $\mathrm{rt}$ for $24 \mathrm{~h}$, protected from a light. The solvent was evaporated and the residue was purified on a silica gel plug $\left(\mathrm{CH}_{2} \mathrm{Cl}_{2} / \mathrm{EtOAc}, 5: 1\right)$ to give the corresponding azo compound as orange-red crystals. Analytically pure samples were obtained by recrystallization (hexane $/ \mathrm{CH}_{2} \mathrm{Cl}_{2}$ ).

2-(2-Fluorophenylazo)picoline (4b): Yield: 83\%: $\mathrm{mp}$ $78-80{ }^{\circ} \mathrm{C} ;{ }^{1} \mathrm{H}$ NMR $\left(300 \mathrm{MHz}, \mathrm{CDCl}_{3}\right) \delta 2.48(\mathrm{~s}, 3 \mathrm{H})$, $7.18-7.34(\mathrm{~m}, 3 \mathrm{H}), 7.48-7.56(\mathrm{~m}, 1 \mathrm{H}), 7.64(\mathrm{~s}, 1 \mathrm{H}), 7.90(\mathrm{t}$, $J=7.7 \mathrm{~Hz}, 1 \mathrm{H}), 8.61(\mathrm{~d}, J=4.4 \mathrm{~Hz}, 1 \mathrm{H}) ;{ }^{13} \mathrm{C} \mathrm{NMR}(100 \mathrm{MHz}$, $\left.\mathrm{CDCl}_{3}\right) \delta 21.2,114.5,117.1(\mathrm{~d}, J=20 \mathrm{~Hz}), 117.9,124.3(\mathrm{~d}$, $J=4 \mathrm{~Hz}), 126.5,133.7$ (d, $J=4 \mathrm{~Hz}), 140.4(\mathrm{~d}, J=6 \mathrm{~Hz})$, 149.3, 149.8, 160.7 (d, $J=258 \mathrm{~Hz}), 163.3$; anal. calcd for $\mathrm{C}_{12} \mathrm{H}_{10} \mathrm{FN}_{3}$ : C, 66.97; H, 4.68; N, 19.52; found: C, 66.93; H, $4.66 ; \mathrm{N}, 19.41$.

2-(2,4-Difluorophenylazo)picoline (4c): Yield 90\%: $\mathrm{mp}$ 99-101 ${ }^{\circ} \mathrm{C} ;{ }^{1} \mathrm{H}$ NMR $\left(300 \mathrm{MHz}, \mathrm{CD}_{3} \mathrm{CN}\right) \delta 2.48$ (s, 3H), 7.14 $(\mathrm{t}, J=8.8 \mathrm{~Hz}, 1 \mathrm{H}), 7.26\left(\mathrm{ddd}, J_{1}=11.3 \mathrm{~Hz}, J_{2}=8.7 \mathrm{~Hz}\right.$, $\left.J_{3}=2.6 \mathrm{~Hz}, 1 \mathrm{H}\right), 7.37(\mathrm{~d}, J=5.0 \mathrm{~Hz}, 1 \mathrm{H}), 7.60(\mathrm{~s}, 1 \mathrm{H}), 7.91$ $\left(\mathrm{dd}, J_{1}=15.3 \mathrm{~Hz}, J_{2}=8.8 \mathrm{~Hz}, 1 \mathrm{H}\right), 8.58(\mathrm{~d}, J=4.8 \mathrm{~Hz}, 1 \mathrm{H})$; ${ }^{1} \mathrm{H}$ NMR $\left(300 \mathrm{MHz}, \mathrm{CDCl}_{3}\right) \delta 2.48(\mathrm{~s}, 3 \mathrm{H}), 6.92-7.08(\mathrm{~m}, 2 \mathrm{H})$, $7.26(\mathrm{~d}, 1 \mathrm{H}), 7.63(\mathrm{~s}, 1 \mathrm{H}), 7.94(\mathrm{~d}, J=8.0 \mathrm{~Hz}, 1 \mathrm{H}), 7.99$ (d, $J=8.6 \mathrm{~Hz}, 1 \mathrm{H}), 8.60(\mathrm{~d}, J=4.6 \mathrm{~Hz}, 1 \mathrm{H}) ;{ }^{13} \mathrm{C} \mathrm{NMR}(100 \mathrm{MHz}$, $\left.\mathrm{CDCl}_{3}\right) \delta 21.1,105.1(\mathrm{t}, J=24 \mathrm{~Hz}), 112.0\left(\mathrm{dd}, J_{1}=27 \mathrm{~Hz}\right.$, $\left.J_{2}=4 \mathrm{~Hz}\right), 114.5,119.3(\mathrm{~d}, J=10 \mathrm{~Hz}), 126.5,137.3(\mathrm{dd}$, $\left.J_{1}=7 \mathrm{~Hz}, J_{2}=4 \mathrm{~Hz}\right), 149.2,149.8,161.2\left(\mathrm{dd}, J_{1}=260 \mathrm{~Hz}\right.$, $\left.J_{2}=7 \mathrm{~Hz}\right), 163.1,165.3\left(\mathrm{dd}, J_{1}=255 \mathrm{~Hz}, J_{2}=12 \mathrm{~Hz}\right)$; UV-vis (MeCN) $\lambda_{\max }(\log \varepsilon) 225$ (4.02), 322 (4.22), 541 (6.61); anal. calcd for $\mathrm{C}_{12} \mathrm{H}_{9} \mathrm{~F}_{2} \mathrm{~N}_{3}: \mathrm{C}, 61.80 ; \mathrm{H}, 3.89 ; \mathrm{N}, 18.02$; found: $\mathrm{C}$, $61.79 ; \mathrm{H}, 3.79 ; \mathrm{N}, 17.92$.

2-(2,4,6-Trifluorophenylazo)picoline (4d): Yield 38\%: ${ }^{1} \mathrm{H}$ NMR $\left(300 \mathrm{MHz}, \mathrm{CD}_{3} \mathrm{CN}\right) \delta 2.49(\mathrm{~s}, 3 \mathrm{H}), 6.85(\mathrm{t}$, $J=8.8 \mathrm{~Hz}, 2 \mathrm{H}), 7.26(\mathrm{~d}, 1 \mathrm{H}), 7.56(\mathrm{~s}, 1 \mathrm{H}), 8.58(\mathrm{~d}, J=4.9 \mathrm{~Hz}$, $1 \mathrm{H}) ;{ }^{1} \mathrm{H}$ NMR $\left(300 \mathrm{MHz}, \mathrm{CDCl}_{3}\right) \delta 2.48(\mathrm{~s}, 3 \mathrm{H}), 7.09(\mathrm{t}$, $J=9.3 \mathrm{~Hz}, 2 \mathrm{H}), 7.26(\mathrm{~d}, 1 \mathrm{H}), 7.61(\mathrm{~s}, 1 \mathrm{H}), 8.61(\mathrm{~d}, J=4.8 \mathrm{~Hz}$, 
$1 \mathrm{H}$ ); HRMS $\mathrm{m} / \mathrm{z}$ calcd for $\mathrm{C}_{12} \mathrm{H}_{9} \mathrm{~F}_{3} \mathrm{~N}_{2}, 252.0749$; found, 252.0738 .

2-(2-Fluoro-5-hydroxymethylphenylazo)picoline (4e): Yield 69\%: mp 154-155 ${ }^{\circ} \mathrm{C}$; ${ }^{1} \mathrm{H}$ NMR $\left(300 \mathrm{MHz}, \mathrm{CDCl}_{3}\right) \delta 2.48(\mathrm{~s}$, $3 \mathrm{H}), 4.73(\mathrm{~s}, 2 \mathrm{H}), 7.28-7.32(\mathrm{~m}, 1 \mathrm{H}), 7.52-7.60(\mathrm{~m}, 1 \mathrm{H}), 7.64$ (s, 1H), $7.88(\mathrm{~d}, J=7.1 \mathrm{~Hz}, 1 \mathrm{H}), 7.60(\mathrm{~d}, J=4.9 \mathrm{~Hz}, 1 \mathrm{H})$; ${ }^{13} \mathrm{C} \mathrm{NMR}\left(100 \mathrm{MHz}, \mathrm{CDCl}_{3}\right) \delta 21.2,64.0,114.3,115.9,117.2$ $(\mathrm{d}, J=20 \mathrm{~Hz}), 126.6,132.2(\mathrm{~d}, J=8 \mathrm{~Hz}), 137.6(\mathrm{~d}, J=4 \mathrm{~Hz})$ $140.0(\mathrm{~d}, J=7 \mathrm{~Hz}), 149.1,150.0,160.0$ (d, $J=257 \mathrm{~Hz}), 163.1$; anal. calcd for $\mathrm{C}_{13} \mathrm{H}_{12} \mathrm{FN}_{3} \mathrm{O}$ : C, 63.66; H, 4.93; N, 17.13; found: $\mathrm{C}, 63.94 ; \mathrm{H}, 4.88 ; \mathrm{N}, 17.20$.

4-Cyano-2-(2-fluorophenylazo)pyridine (4f): Method B. 4-Cyano-2-aminopyridine (238 mg, $2.0 \mathrm{mmol})$ was dissolved in toluene $(3 \mathrm{~mL})$ and a $50 \%$ aqueous solution of $\mathrm{NaOH}(1.5 \mathrm{~mL})$ and 2-fluoronitrosobenzene [7] $(\mathbf{9}, 293 \mathrm{mg}, 2.3 \mathrm{mmol})$ was added. The mixture was vigorously stirred at $50{ }^{\circ} \mathrm{C}$ for $25 \mathrm{~min}$. After cooling, water was added, and the mixture was extracted with $\mathrm{CH}_{2} \mathrm{Cl}_{2}$. Extracts were dried over $\mathrm{Na}_{2} \mathrm{SO}_{4}$, and the solvent was evaporated. The residue was purified by column chromatography $\left(\mathrm{SiO}_{2}\right.$, hexane $\left./ \mathrm{CH}_{2} \mathrm{Cl}_{2}\right)$ to give $230 \mathrm{mg}$ (50\% yield) of azo derivative $4 \mathbf{f}$ as an orange solid: ${ }^{1} \mathrm{H}$ NMR $(300 \mathrm{MHz}$, $\left.\mathrm{CD}_{3} \mathrm{CN}\right) \delta 7.34(\mathrm{t}, J=7.8 \mathrm{~Hz}, 1 \mathrm{H}), 7.41(\mathrm{t}, J=9.7 \mathrm{~Hz}, 1 \mathrm{H})$, $7.62-7.72(\mathrm{~m}, 1 \mathrm{H}), 7.76-7.88(\mathrm{~m}, 2 \mathrm{H}), 8.02(\mathrm{~s}, 1 \mathrm{H}), 8.89(\mathrm{~d}$, $J=4.9 \mathrm{~Hz}, 1 \mathrm{H}) ;{ }^{1} \mathrm{H}$ NMR $\left(300 \mathrm{MHz}, \mathrm{CDCl}_{3}\right) \delta 7.27-7.41(\mathrm{~m}$, 2H), 7.56-7.61 (m, 1H), $7.66(\mathrm{~d}, J=5.0 \mathrm{~Hz}, 1 \mathrm{H}), 8.05(\mathrm{~s}, 1 \mathrm{H})$, $8.93(\mathrm{~d}, J=4.9 \mathrm{~Hz}, 1 \mathrm{H}) ;{ }^{13} \mathrm{C} \mathrm{NMR}\left(100 \mathrm{MHz}, \mathrm{CD}_{3} \mathrm{CN}\right) \delta$, 116.8, 117.0, 118.2, 118.3, 123.2, 125.6 (d, $J=6 \mathrm{~Hz}), 127.9$, $135.9(\mathrm{~d}, J=8 \mathrm{~Hz}), 140.7(\mathrm{~d}, J=7 \mathrm{~Hz}), 151.4,161.3(\mathrm{~d}$, $J=257 \mathrm{~Hz}$ ), 164.0; anal. calcd for $\mathrm{C}_{12} \mathrm{H}_{7} \mathrm{FN}_{4}: \mathrm{C}, 63.71 ; \mathrm{H}$, 3.12; N, 24.77; found: C, 63.81; H, 3.14; N, 24.61 .

\section{Supporting Information}

\section{Supporting Information File 1}

General methods and synthetic procedures.

[http://www.beilstein-journals.org/bjoc/content/ supplementary/1860-5397-9-219-S1.pdf]
2. Roomans, G. M. Am. J. Respir. Med. 2003, 2, 413-431. doi:10.1007/BF03256668

3. Prost, A.-L.; Dérand, R.; Gros, L.; Becq, F.; Vivaudou, M. Biochem. Pharmacol. 2003, 66, 425-430. doi:10.1016/S0006-2952(03)00289-2

4. Galietta, L. J. V.; Springsteel, M. F.; Eda, M.; Niedzinski, E. J.; By, K.; Haddadin, M. J.; Kurth, M. J.; Nantz, M. H.; Verkman, A. S. J. Biol. Chem. 2001, 276, 19723-19728. doi:10.1074/jbc.M101892200

5. Sinan, M.; Panda, M.; Ghosh, A.; Dhara, K.; Fanwick, P. E.; Chattopadhyay, D. J.; Goswami, S. J. Am. Chem. Soc. 2008, 130, 5185-5193. doi:10.1021/ja710211u

6. Garza-Ortiz, A.; den Dulk, H.; Brouwer, J.; Kooijman, H.; Spek, A. L.; Reedijk, J. J. Inorg. Biochem. 2007, 101, 1922-1930. doi:10.1016/j.jinorgbio.2007.05.008

7. Jankowiak, A.; Obijalska, E.; Kaszynski, P.; Pieczonka, A.; Young, V. G., Jr. Tetrahedron 2011, 67, 3317-3327. doi:10.1016/j.tet.2011.03.023

8. Taylor, E. C.; Tseng, C. P.; Rampal, J. B. J. Org. Chem. 1982, 47, 552-555. doi:10.1021/jo00342a035

9. Carroll, W. A.; Altenbach, R. J.; Bai, H.; Brioni, J. D.; Brune, M. E.; Buckner, S. A.; Cassidy, C.; Chen, Y.; Coghlan, M. J.; Daza, A. V.; Drizin, I.; Fey, T. A.; Fitzgerald, M.; Gopalakrishnan, M.; Gregg, R. J.; Henry, R. F.; Holladay, M. W.; King, L. L.; Kort, M. E.; Kym, P. R.; Milicic, I.; Tang, R.; Turner, S. C.; Whiteaker, K. L.; Yi, L.; Zhang, H.; Sullivan, J. P. J. Med. Chem. 2004, 47, 3163-3179. doi:10.1021/jm030356w

10. Campbell, N.; Henderson, A. W.; Taylor, D. J. Chem. Soc. 1953, 1281-1285. doi:10.1039/jr9530001281

11. Obijalska, E.; Kaszynski, P.; Jankowiak, A.; Young, V. G. Polyhedron 2011, 30, 1339-1348. doi:10.1016/j.poly.2011.02.023

12. García-Amorós, J.; Velasco, D. Beilstein J. Org. Chem. 2012, 8, 1003-1017. doi:10.3762/bjoc.8.113

13. Manka, J. T.; McKenzie, V. C.; Kaszynski, P. J. Org. Chem. 2004, 69, 1967-1971. doi:10.1021/jo0302399

14. Fryszkowska, A.; Tilford, R. W.; Guo, F.; Kaszynski, P. Tetrahedron 2005, 61, 2327-2333. doi:10.1016/j.tet.2005.01.023

15. Katritzky, A. R.; Barczynski, P.; Musumarra, G.; Pisano, D.; Szafran, M. J. Am. Chem. Soc. 1989, 111, 7-15. doi:10.1021/ja00183a002

16. Gaussian 09, Revision A.02; Gaussian, Inc.: Wallingford, CT, 2009.

17. Scott, A. P.; Radom, L. J. Phys. Chem. 1996, 100, 16502-16513. doi:10.1021/jp960976r

18. Peng, C.; Ayala, P. Y.; Schlegel, H. B.; Frisch, M. J. J. Comput. Chem. 1996, 17, 49-56. doi:10.1002/(SICI)1096-987X(19960115)17:1<49::AID-JCC5>3.3.CO;2 \#

19. Foresman, J. B.; Keith, T. A.; Wiberg, K. B.; Snoonian, J.; Frisch, M. J. J. Phys. Chem. 1996, 100, 16098-16104. doi:10.1021/jp960488j

\section{Acknowledgements}

Financial support for this work was received from the Petroleum Research Funds (PRF-47243-AC4) and the National Science Foundation (OISE-0532040 and CHE-1214104).

\section{References}

1. Norez, C.; Bilan, F.; Kitzis, A.; Mettey, Y.; Becq, F.

J. Pharmacol. Exp. Ther. 2008, 325, 89-99.

doi:10.1124/jpet.107.134502 


\section{License and Terms}

This is an Open Access article under the terms of the Creative Commons Attribution License

(http://creativecommons.org/licenses/by/2.0), which permits unrestricted use, distribution, and reproduction in any medium, provided the original work is properly cited.

The license is subject to the Beilstein Journal of Organic Chemistry terms and conditions:

(http://www.beilstein-journals.org/bjoc)

The definitive version of this article is the electronic one which can be found at:

doi:10.3762/bjoc.9.219 